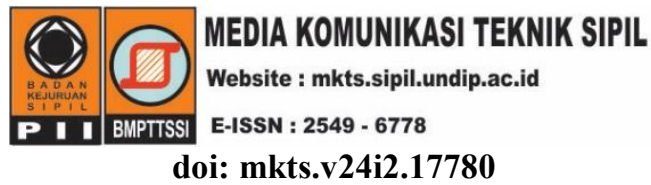

\title{
Analisis Pengaruh Fluktuasi Muka Air Waduk terhadap Stabilitas Lereng Waduk Dengan Menggunakan Program Plaxis 2D
}

\author{
Paravita Sri Wulandari, "Daniel Tjandra \\ Fakultas Teknik Sipil dan Perencanaan, Universitas Kristen Petra, Surabaya \\ ${ }^{*}$ danieltj@petra.ac.id
}

Received: 23 Februari 2018 Revised: 3 Oktober 2018 Accepted: 5 Oktober 2018

\begin{abstract}
Reservoir is needed as a source of water supply to the surrounding populations. The design of a reservoir needs to consider several aspects of soil embankment such as variations in water content and changes in shear soil shear strength and also the influence of water level in reservoir. The purpose of this research is to analyze these three aspects in the design of a reservoir. This research was begun by taking soil samples for embankment and conducting soil tests to obtain soil characteristics at the initial condition. The further laboratory tests were conducted to determine the effect of changes in water content on the shear strength of the soil. The variation of soil embankment characteristic was then modeled by Plaxis $2 D$ program to obtain the effect of changes in soil embankment characteristic and fluctuation of the water level in the reservoir. The results showed that the increase in water content significantly decrease the shear strength of the soil. The changes of soil shear strength affect the pattern of slope failure and safety factor. In addition, the pattern and direction of the slope failure were also influenced by the water level of the reservoir.
\end{abstract}

Keywords: Water content variation, soil shear strength, water table fluctuation, safety factor

\begin{abstract}
Abstrak
Waduk merupakan sarana yang tepat untuk memenuhi kebutuhan air penduduk di sekitarnya. Perencanaan sebuah waduk perlu memperhatikan beberapa aspek seperti variasi kadar air, perubahan kuat geser tanah timbunan dan pengaruh ketinggian muka air waduk. Tujuan dari penelitian ini adalah untuk menganalisis ketiga aspek tersebut dalam perencanaan sebuah waduk. Penelitian ini dimulai dengan mengambil contoh tanah timbunan dan melakukan pengujian untuk mendapatkan karakteristik tanah pada kondisi awal. Setelah itu dilakukan pengujian untuk mengetahui pengaruh perubahan kadar air terhadap kuat geser tanah. Hasil variasi karakteristik tanah timbunan yang didapatkan kemudian dimodelkan dengan menggunakan bantuan program Plaxis $2 D$ untuk mengetahui pengaruh dari perubahan karakteristik tanah timbunan dan fluktuasi muka air pada waduk. Hasil penelitian menunjukkan bahwa peningkatan kadar air dapat menurunkan kuat geser tanah secara signifikan. Kuat geser tanah timbunan mempengaruhi pola kelongsoran lereng dan angka keamanan timbunan. Selain itu pola dan arah kelongsoran lereng juga dipengaruhi oleh ketinggian muka air waduk.
\end{abstract}

Kata kunci: Variasi kadar air, kuat geser tanah, fluktuasi muka air, angka keamanan

\section{Pendahuluan}

Seiring dengan pertambahan penduduk, penyediaan air perlu diatur dengan baik mengingat pada musim kemarau di beberapa tempat mengalami kekurangan air. Sebaliknya di tempat yang sama pada musim hujan dapat terjadi kelebihan air bahkan mengakibatkan bencana banjir. Pembangunan waduk dapat dilakukan sebagai salah satu upaya untuk mengatur penyediaan air. Perencanaan sebuah waduk harus dilakukan dengan mempertimbangkan beberapa aspek. Salah satu aspek yang harus mendapat perhatian dengan seksama adalah fluktuasi muka air di dalam waduk. Naik dan turunnya muka air di dalam sebuah waduk dapat berpengaruh terhadap kestabilan lereng waduk, terutama ketika perubahan muka air terjadi dengan cepat 
(Shivamanth et al., 2015). Penurunan kestabilan lereng dapat menimbulkan potensi terjadinya kelongsoran. Variasi ketinggian muka air tanah ini dapat terjadi saat perubahan musim hujan ke musim kemarau dan sebaliknya. Beberapa penelitian yang sudah dilakukan menunjukkan bahwa ketinggian muka air tanah juga mempengaruhi kestabilan sebuah lereng (Rahardjo et al., 2010). Kestabilan lereng dapat dipengaruhi oleh perubahan tekanan air di dalam tanah, dimana perubahan ini dapat menyebabkan perubahan pada kuat geser tanah. Keming \& Bagale (2012) juga mengemukakan di hasil penelitiannya bahwa angka keamanan lereng berkaitan dengan perubahan tinggi muka air akibat infiltrasi air hujan di dalam tanah. Penelitian yang dilakukan oleh Chen \& Huang (2011) juga menunjukkan bahwa fluktuasi muka air pada dan dapat menyebabkan terjadinya keruntuhan pada lereng.

Kestabilan sebuah lereng dapat dilihat dari angka keamanan lereng, dimana angka keamanan sebuah lereng dapat mengalami penurunan ketika musim hujan. Saat musim hujan, air dimungkinkan untuk masuk ke dalam lereng waduk. Penetrasi air ke dalam tanah dapat meningkatkan nilai kadar air dalam tanah yang pada akhirnya dapat menurunkan kuat geser tanah secara signifikan (Tjandra et al., 2013, Tjandra et al., 2014, Tjandra et al., 2015). Hal ini juga ditunjukkan oleh Khanmohammadi \& Hosseinitoudeshki (2014) bahwa penetrasi air ke dalam tanah akibat kenaikan muka air tanah dapat menurunkan kekuatan tanah dan angka keamanan lereng. Penelitian yang telah dilakukan oleh Liu \& Li (2015) juga menunjukkan hasil bahwa penetrasi air dan variasi muka air tanah dapat mempengaruhi kestabilan lereng. Andreea (2016) juga mengemukakan bahwa masuknya air ke dalam lereng menyebabkan permasalahan pada kestabilan lereng tersebut. Kehilangan kekuatan pada material lereng disebabkan karena naiknya tegangan air pori tanah dan derajat kejenuhan tanah.

Dalam makalah ini akan dibahas beberapa aspek yang berpengaruh dalam sebuah perencanaan waduk. Beberapa aspek tersebut adalah variasi kadar air, perubahan kuat geser dari tanah timbunan sebagai dampak dari perubahan kadar air dan pengaruh ketinggian muka air waduk. Ketiga aspek tersebut tentunya dapat berpengaruh pada angka keamanan dari lereng waduk tersebut. Analisis dilakukan dengan pemodelan lereng waduk dengan menggunakan Plaxis 2D. Parameter yang dihasilkan dari pemodelan dengan Plaxis 2D ini berupa angka keamanan dan pola kelongsoran lereng waduk.

\section{Metode Penelitian}

\section{Pengujian karakteristik tanah}

Pemodelan kondisi waduk dan tanah timbunan di samping waduk dilakukan dengan menggunakan PLAXIS 2D. Beberapa jenis pengujian laboratorium dilakukan untuk mendapatkan parameter karakteristik tanah timbunan di samping waduk dengan prosedur pengujian laboratorium yang dilakukan mengacu pada American Standard Testing and Material (ASTM).

Sampel tanah yang digunakan dalam pengujian laboratorium adalah untuk mewakili kondisi tanah timbunan di samping waduk. Sampel tanah yang digunakan berupa tanah kelempungan yang diambil dari sebuah lokasi di daerah Krikilan, Sidoarjo.

Parameter tanah dasar waduk yang digunakan dalam pemodelan dengan PLAXIS 2D diperoleh dari hasil penyelidikan tanah lapangan, dengan jenis-jenis pengujian laboratorium seperti yang ditampilkan pada Tabel 1.

Tabel 1. Jenis pengujian laboratorium

\begin{tabular}{clc}
\hline No & \multicolumn{1}{c}{ Jenis Pengujian } & Standar ASTM \\
\hline 1 & Liquid limit & D-4318 \\
2 & Plastic limit & D-4318 \\
3 & Shrinkage limit & D-427-04 \\
4 & Proctor test & D-1557 \\
5 & California bearing ratio & D-1883-99 \\
6 & Falling head test & D-2434-68 \\
\hline
\end{tabular}

\section{Pemodelan geometri pada Plaxis 2D}

Pemodelan penampang waduk berdasarkan data dari lokasi perencanaan waduk di Gunung Eleh Sampang, Madura. Penampang perencanaan waduk dan hasil penyelidikan tanah pada lokasi tersebut dapat dilihat pada Gambar 1. Data yang digunakan sebagai input parameter pada Plaxis 2D adalah parameter karakteristik tanah dasar dan tanah timbunan. Data tersebut diperoleh dari hasil penyelidikan tanah di lapangan dan hasil pengujian tanah di laboratorium.

Tabel 2 menunjukkan karakteristik fisik dan mekanik tanah dasar waduk yang digunakan sebagai input parameter di program Plaxis 2D. Tanah dasar waduk ini terbagi menjadi dua lapisan, dimana lapisan pertama berupa lempung kelanauan sedangkan lapisan kedua merupakan lempung sangat kaku. 


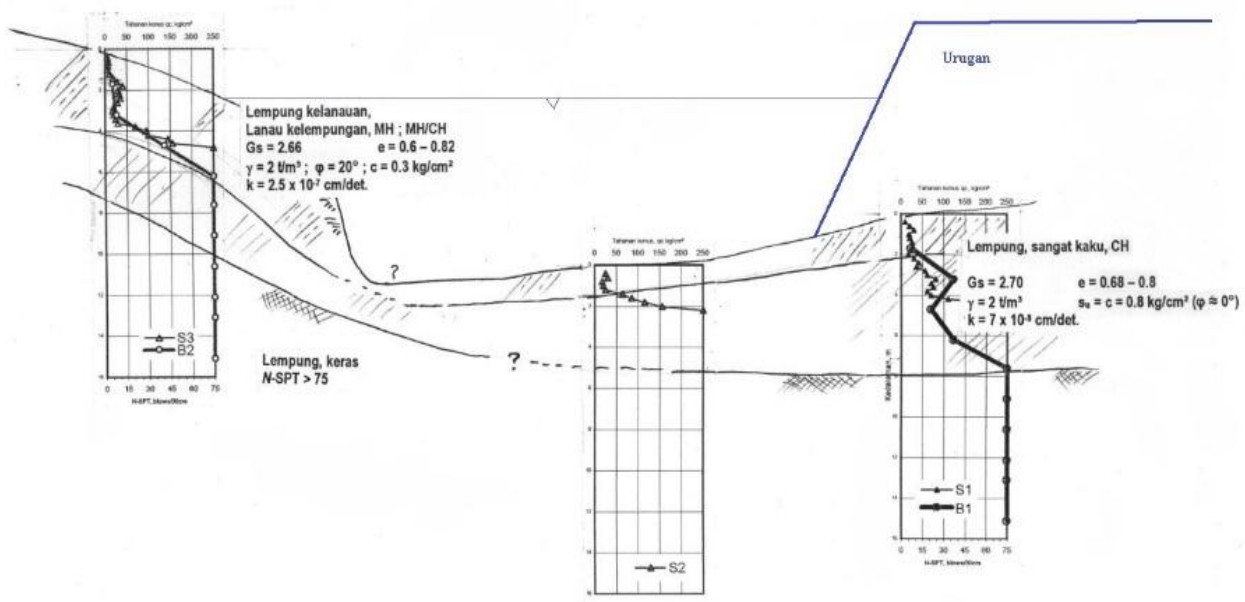

Gambar 1. Penampang waduk

Tabel 2. Karakteristik tanah dasar waduk

\begin{tabular}{lcc}
\hline \multicolumn{1}{c}{ Parameter } & $\begin{array}{c}\text { Lapisan } \\
\text { lempung } \\
\text { kelanauan }\end{array}$ & $\begin{array}{c}\text { Lapisan } \\
\text { lempung } \\
\text { sangat kaku }\end{array}$ \\
\hline$\gamma_{\text {dry }}\left(\mathrm{kN} / \mathrm{m}^{3}\right)$ & 18 & 18 \\
$\gamma_{\text {wet }}\left(\mathrm{kN} / \mathrm{m}^{3}\right)$ & 20 & 20 \\
$\mathrm{k}_{\mathrm{x}}(\mathrm{m} /$ day $)$ & $2,16 \mathrm{E}-04$ & $6,05 \mathrm{E}-05$ \\
$\mathrm{k}_{\mathrm{y}}(\mathrm{m} /$ day $)$ & $2,16 \mathrm{E}-04$ & $6,05 \mathrm{E}-05$ \\
$\mathrm{c}\left(\mathrm{kN} / \mathrm{m}^{2}\right)$ & 30 & 80 \\
$\phi$ & 20 & 0 \\
\hline
\end{tabular}

Dalam pemodelan waduk dan tanah timbunan di samping waduk dengan PLAXIS 2D, diterapkan variasi ketinggian muka air tanah dalam waduk. Muka air tanah waduk divariasikan dalam empat kondisi yaitu: tanpa muka air tanah, muka air tanah berada di permukaan tanah timbunan, di setengah bagian dari tinggi tanah timbunan dan di dasar waduk.

\section{Hasil dan Pembahasan}

\section{Karakteristik tanah timbunan pada lereng waduk}

Pada Tabel 3 ditunjukkan hasil pengujian laboratorium pada sampel tanah timbunan. Dari hasil pengujian batas Atterberg yang diterapkan pada diagram plastisitas yang dikemukakan oleh Casagrande, tanah tersebut dapat diklasifikasikan sebagai tanah lempung lanau $\mathrm{MH}-\mathrm{CH}$.

Tabel 3. Karakteristik tanah timbunan

\begin{tabular}{cc}
\hline Jenis pengujian & Hasil \\
\hline Liquid limit $(\%)$ & 77,57 \\
Plastic limit $(\%)$ & 33,93 \\
Shrinkage limit $(\%)$ & 9,49 \\
Plasticity Index (\%) & 43,63 \\
Klasifikasi tanah & MH-CH \\
k (m/day) & $6,05 \mathrm{E}-05$ \\
\hline
\end{tabular}

Pengujian proctor dilakukan untuk mengetahui kadar air optimum $\left(\mathrm{w}_{\mathrm{c} \text { opt }}\right)$ dan kepadatan kering maksimum $\left(\gamma_{\text {dmax }}\right)$ dari tanah timbunan pada lereng waduk. Hasil dari pengujian proctor dapat dilihat pada Gambar 2, dimana nilai $\mathrm{w}_{\mathrm{c} \text { opt }}$ adalah sebesar $14,20 \%$ dan $\gamma_{\text {dmax }}$ adalah sebesar 1,65 gr/ $\mathrm{cm}^{3}$. Dari hasil pengujian ini diperoleh variasi berat volume pada setiap kadar air tertentu, yang kemudian digunakan sebagai sampel untuk pengujian california bearing ratio (CBR). Dari hasil pengujian CBR pada setiap kondisi kadar air, diperoleh hubungan antara nilai CBR dengan kadar air tanah.

Hubungan antara nilai CBR dan kadar air tanah ditunjukkan pada Gambar 3. Terlihat bahwa sejalan dengan bertambahnya kadar air tanah, nilai CBR tanah mengalami penurunan. Dimana penurunan nilai $\mathrm{CBR}$ menunjukkan terjadinya penurunan kuat geser tanah. Dari hasil pengujian didapatkan nilai CBR tertinggi yaitu $35,39 \%$ sedangkan nilai CBR yang terendah yaitu $1,14 \%$. Penurunan nilai CBR secara drastis terjadi setelah kadar air melewati batas susut yaitu sebesar $9,49 \%$. Penurunan yang drastis tersebut terjadi hingga batas plastis tanah yaitu sebesar 33,93\%. Hal ini disebabkan karena perubahan fase tanah dari kondisi padat ke kondisi plastis. Sedangkan saat kadar air tanah naik melewati batas plastis, nilai CBR mengalami penurunan yang tidak signifikan.

\section{Korelasi antara CBR terhadap kuat geser undrained $\left(\mathrm{c}_{\mathrm{u}}\right)$}

Pada penelitian ini, kuat geser tanah diperoleh dari hasil korelasi nilai CBR tanah. Hal ini disebabkan karena kuat geser tanah sulit didapatkan dengan menggunakan triaxial test maupun unconfined compression test. Pada saat persiapan sampel tanah untuk kedua pengujian tersebut, sampel tanah tidak dapat dibentuk dari tanah yang berada di dalam 


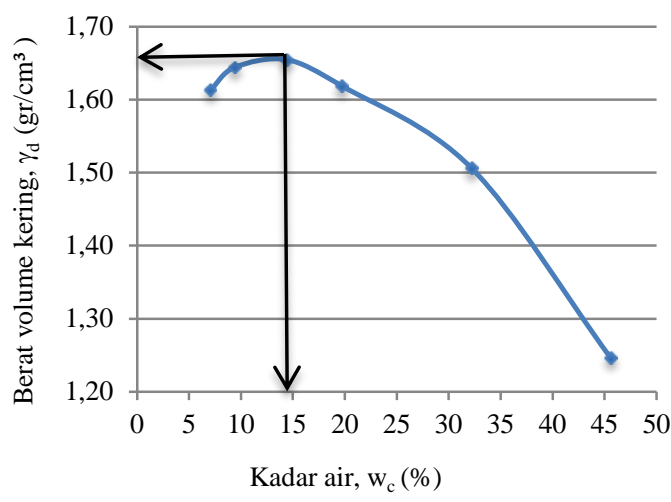

Gambar 2. Hubungan kadar air dengan berat volume kering

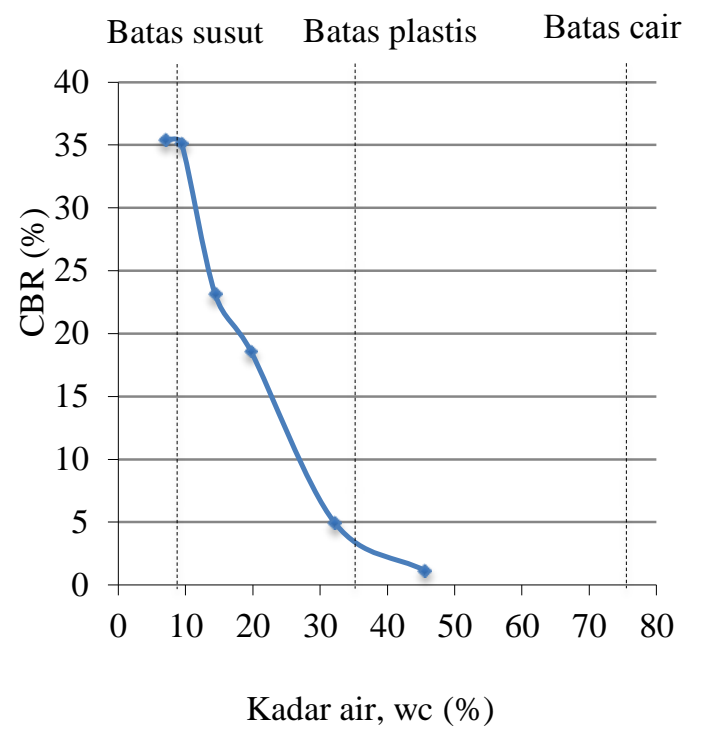

Gambar 3. Hubungan antara CBR dan kadar air

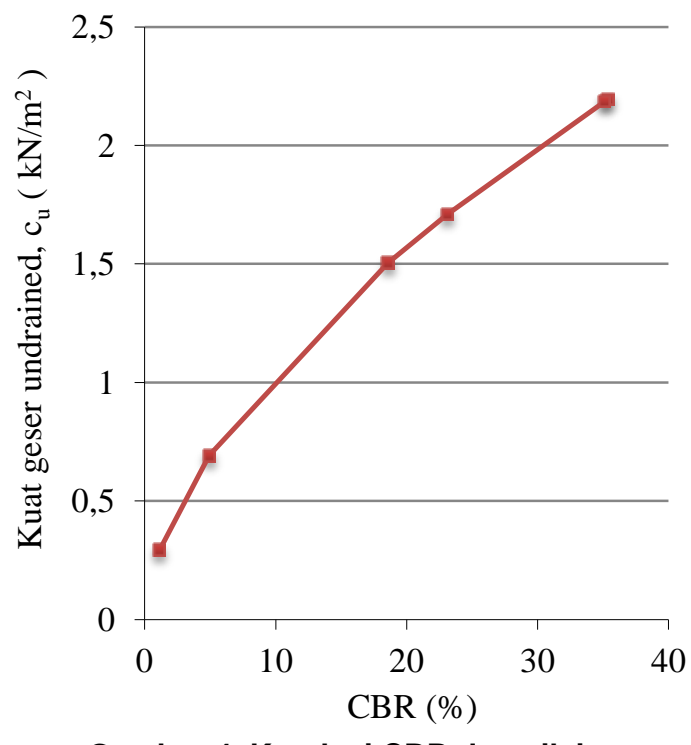

Gambar 4. Korelasi CBR dan nilai $c_{u}$ tabung proctor test. Oleh karena itu, setelah pengujian proctor dilakukan pengujian CBR pada tanah di dalam tabung proctor pada setiap kondisi kadar air untuk mendapatkan kuat geser tanah. Nilai kuat geser undrained $\left(\mathrm{c}_{\mathrm{u}}\right)$ didapatkan dari hasil korelasi CBR terhadap $\mathrm{c}_{\mathrm{u}}$ yang dikemukakan oleh Jenkins \& Kerr (1998) dengan Persamaan 1.

$\mathrm{c}_{\mathrm{u}}=27,15 \mathrm{CBR}^{0.586}$

Korelasi nilai $\mathrm{c}_{\mathrm{u}}$ terhadap nilai CBR tanah pada setiap variasi kondisi kadar air ditunjukkan pada Gambar 4. Nilai $c_{u}$ ini digunakan sebagai input parameter kuat geser tanah timbunan pada saat simulasi menggunakan program Plaxis 2D.

\section{Analisis menggunakan program Plaxis 2D}

Hasil semua jenis pengujian tanah yang dilakukan di laboratorium ditunjukkan pada Tabel 4 dan Gambar 2 sampai dengan 4. Hasil pengujian ini kemudian digunakan sebagai input parameter tanah timbunan pada program Plaxis 2D. Parameter lain seperti modulus elastisitas dan poison ratio ditentukan dari contoh parameter global di Plaxis.

Variasi muka air tanah (MAT) yang ditinjau ada empat kondisi yaitu tanpa muka air tanah, MAT.1, 2, dan 3. Kondisi MAT.1 adalah kondisi saat muka air waduk berada di permukaan tanah timbunan. MAT.2 adalah kondisi saat muka air waduk mencapai setengah ketinggian timbunan. MAT.3 adalah kondisi saat muka air berada di dasar waduk.

Pemodelan perencanaan waduk, dimensi waduk beserta dengan variasi MAT di dalam waduk pada Plaxis 2D dapat dilihat pada Gambar 5.

Dalam penelitian ini, tanah timbunan merupakan tanah kelempungan dengan permeabilitas rendah. Tanah timbunan di samping waduk digunakan untuk menahan air agar tidak merembes keluar dari lokasi waduk. Pada saat muka air waduk mengalami penurunan secara cepat, diasumsikan muka air tanah timbunan masih dalam posisi awal dan tidak mengalami penurunan.

Salah satu faktor yang menunjukkan kestabilan sebuah lereng adalah angka keamanan. Variasi kadar air menyebabkan variasi kuat geser tanah dan pada akhirnya menyebabkan variasi angka keamanan lereng. Pada Gambar 6 dapat dilihat bahwa angka keamanan semakin meningkat ketika kuat geser tanah meningkat. Hal ini terjadi pada semua kondisi, yaitu: tanpa muka air tanah, MAT.1, 2 dan 3. 
Tabel 4. Karakteristik tanah timbunan dengan variasi kadar air

\begin{tabular}{crrrrrr}
\hline Parameter & \multicolumn{5}{c}{ Tanah timbunan } \\
\hline $\mathrm{w}_{\mathrm{c}}(\%)$ & 7,06 & 9,39 & 14,40 & 19,72 & 32,21 & 45,60 \\
$\gamma_{\text {dry }}\left(\mathrm{kN} / \mathrm{m}^{3}\right)$ & 16,10 & 16,40 & 16,50 & 16,20 & 15,10 & 12,50 \\
$\gamma_{\text {wet }}\left(\mathrm{kN} / \mathrm{m}^{3}\right)$ & 17,30 & 18,00 & 18,90 & 19,40 & 19,90 & 18,10 \\
$\mathrm{k}_{\mathrm{x}}(\mathrm{m} /$ day $)$ & 0,00 & 0,00 & 0,00 & 0,00 & 0,00 & 0,00 \\
$\mathrm{k}_{\mathrm{y}}(\mathrm{m} /$ day) & 0,00 & 0,00 & 0,00 & 0,00 & 0,00 & 0,00 \\
$\mathrm{c}_{\mathrm{u}}\left(\mathrm{kN} / \mathrm{m}^{2}\right)$ & 219,50 & 218,60 & 171,10 & 150,50 & 69,20 & 29,30 \\
$\phi$ & 1,00 & 1,00 & 1,00 & 1,00 & 1,00 & 1,00 \\
\hline
\end{tabular}

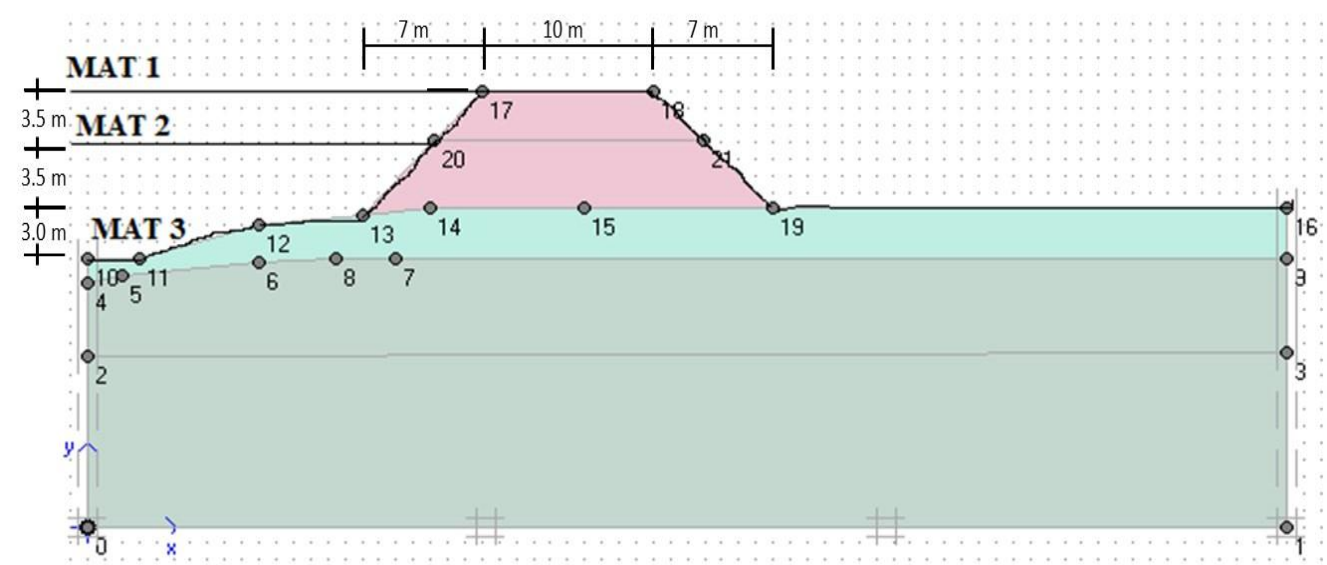

Gambar 5. Fluktuasi muka air tanah waduk

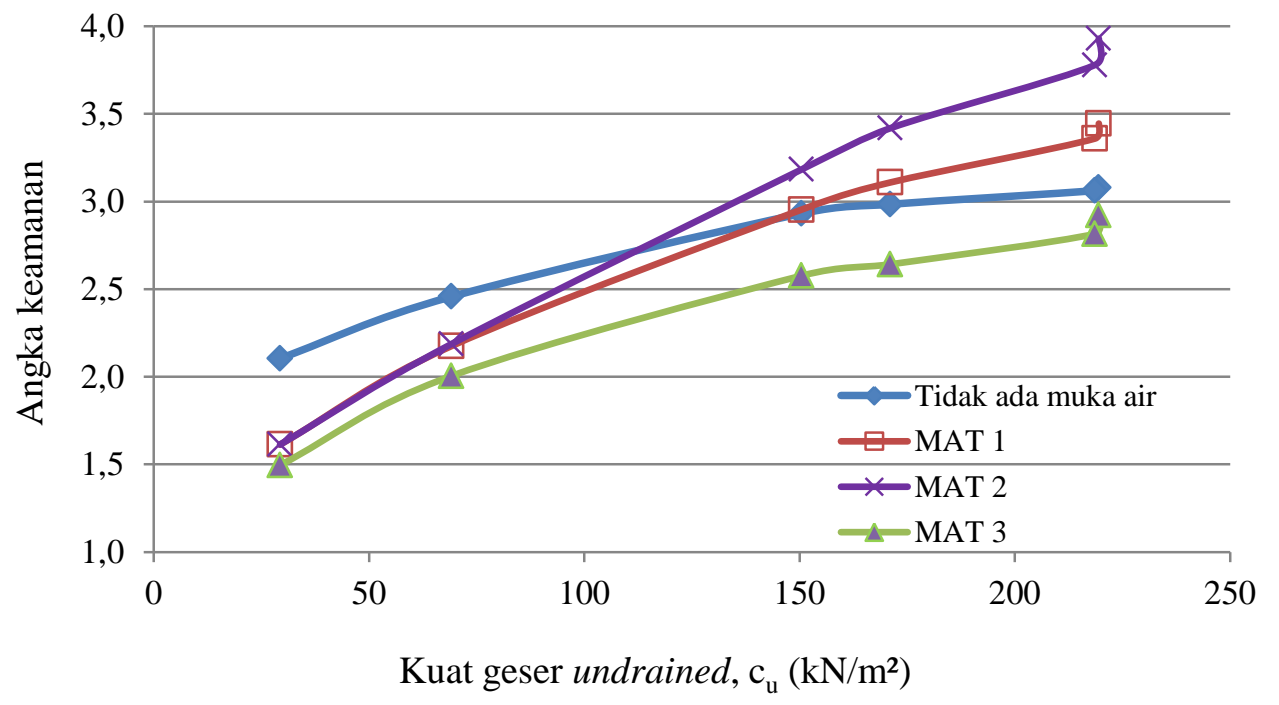

Gambar 6. Variasi angka keamanan akibat perubahan kuat geser tanah dengan fluktuasi muka air tanah

Gambar 6 juga menunjukkan adanya peningkatan angka keamanan tanah timbunan di samping waduk. Peningkatan yang terjadi terlihat lebih signifikan seiring dengan peningkatan kuat geser tanah pada kondisi MAT.1 dan 2, dibandingkan dengan kondisi tidak ada muka air tanah maupun kondisi MAT 3. Hal ini disebabkan karena adanya muka air waduk menimbulkan gaya yang melawan gaya longsor yang terjadi, khususnya ketika tanah timbunan di samping waduk memiliki kuat geser yang besar. Secara umum, adanya muka air pada tanah timbunan dapat menyebabkan penurunan angka keamanan. Hal ini terlihat di Gambar 6 pada kondisi MAT.3 dimana muka air tanah berada tepat di dasar waduk. Pada setiap nilai kuat geser tanah, angka keamanan lereng lebih rendah sekitar 0,5 bila dibandingkan dengan kondisi tidak ada muka air. Penurunan angka keamanan ini 
disebabkan adanya peningkatan tegangan air pori sehingga tegangan efektif tanah mengalami penurunan. Selain itu, peningkatan kadar air dan derajat kejenuhan tanah dapat menyebabkan tanah tersebut kehilangan kekuatan gesernya dan pada akhirnya mengurangi gaya penahan kelongsoran pada lereng tersebut. Pada saat kadar air tinggi, dimana kadar air melebihi kadar air optimum $\left(\mathrm{w}_{\mathrm{c}}>\right.$ $\mathrm{w}_{\mathrm{c} \text { opt }}$ ), dan kuat geser tanah rendah, kenaikan muka air tanah waduk menyebabkan penurunan angka keamanan lereng. Akan tetapi ketika kadar air rendah, dimana kadar air berkurang atau mendekati kadar air optimum $\left(\mathrm{w}_{\mathrm{c}} \leq \mathrm{w}_{\mathrm{c} \text { opt }}\right)$, dan kuat geser tanah tinggi, kenaikan muka air tanah waduk menyebabkan peningkatan angka keamanan. Fenomena ini dapat dijelaskan dengan melihat perubahan pola kelongsoran saat terjadi fluktuasi muka air tanah seperti terlihat pada Gambar 7 sampai dengan 14.

Fenomena pola arah kelongsoran lereng yang terjadi pada tanah timbunan dengan kuat geser rendah ternyata sama dengan pola kelongsoran pada tanah timbunan dengan kuat geser tinggi. Pada saat tidak ada muka air tanah maupun pada saat muka air tanah berada di bawah timbunan atau di dasar waduk, pola kelongsoran lereng waduk hanya berada pada tanah timbunan dan bergerak ke arah kiri yaitu ke arah waduk. Kondisi kelongsoran lereng timbunan ini dapat dilihat pada Gambar 11 dan 14.

Peningkatan muka air tanah ke kondisi MAT 1 dan 2 menyebabkan perubahan arah kelongsoran pada tanah timbunan. Pada Gambar 12 dan 13 terlihat kelongsoran lereng bergerak dari kiri ke arah kanan. Perubahan arah kelongsoran ini disebabkan adanya beban air yang melawan gaya longsor sehingga arah kelongsoran berbalik arah. Pada saat tidak ada muka air tanah maupun pada saat muka air tanah berada di dasar waduk, pola kelongsoran lereng waduk berada di dasar lereng dan bergerak ke arah kiri yaitu ke arah waduk. Kondisi ini seperti terlihat pada Gambar 7 dan Gambar 10.

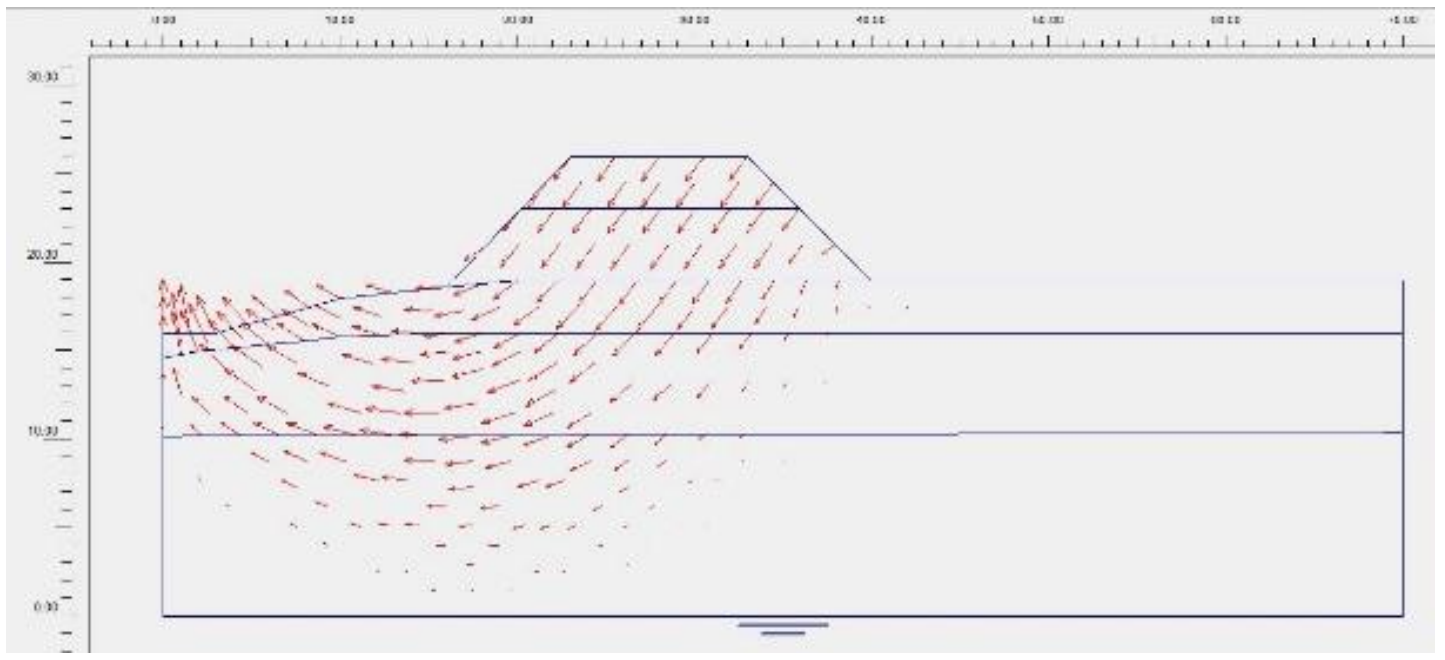

Gambar 7. Pola kelongsoran dengan kuat geser tanah timbunan tinggi (tidak ada MAT.)

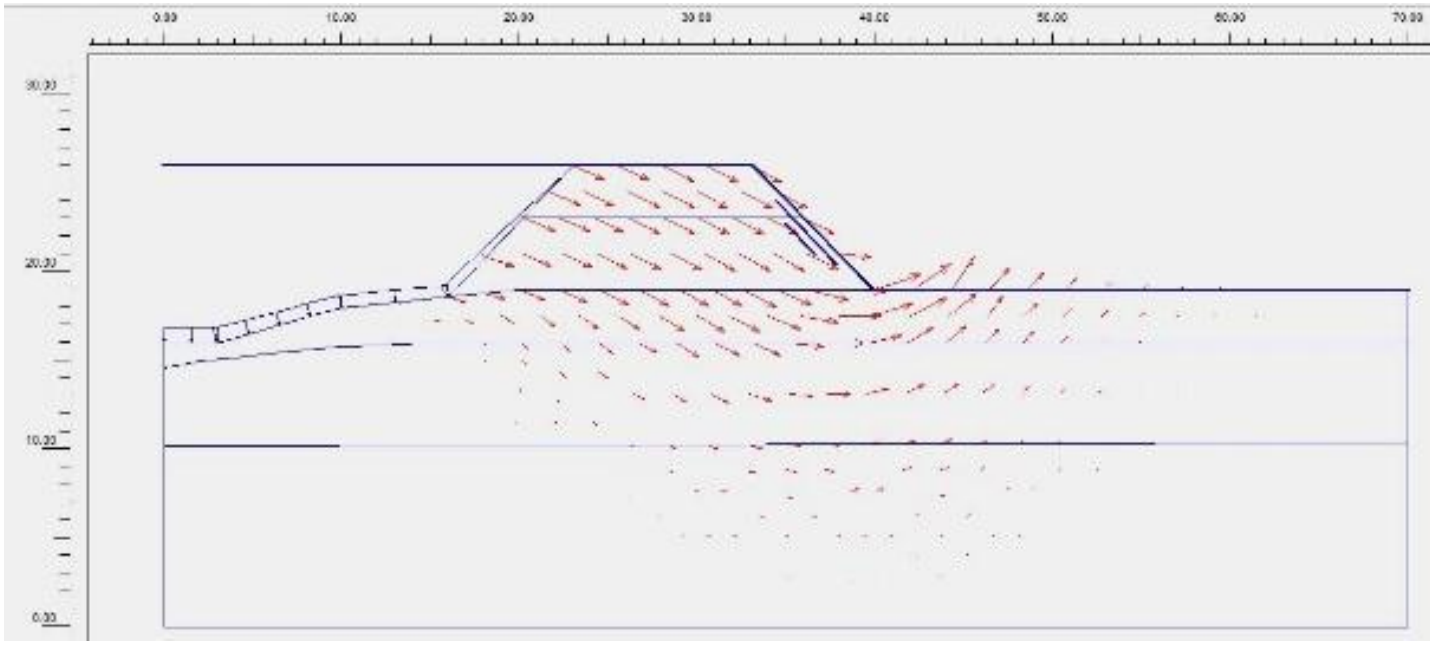

Gambar 8. Pola kelongsoran dengan kuat geser tanah timbunan tinggi (kondisi MAT.1) 


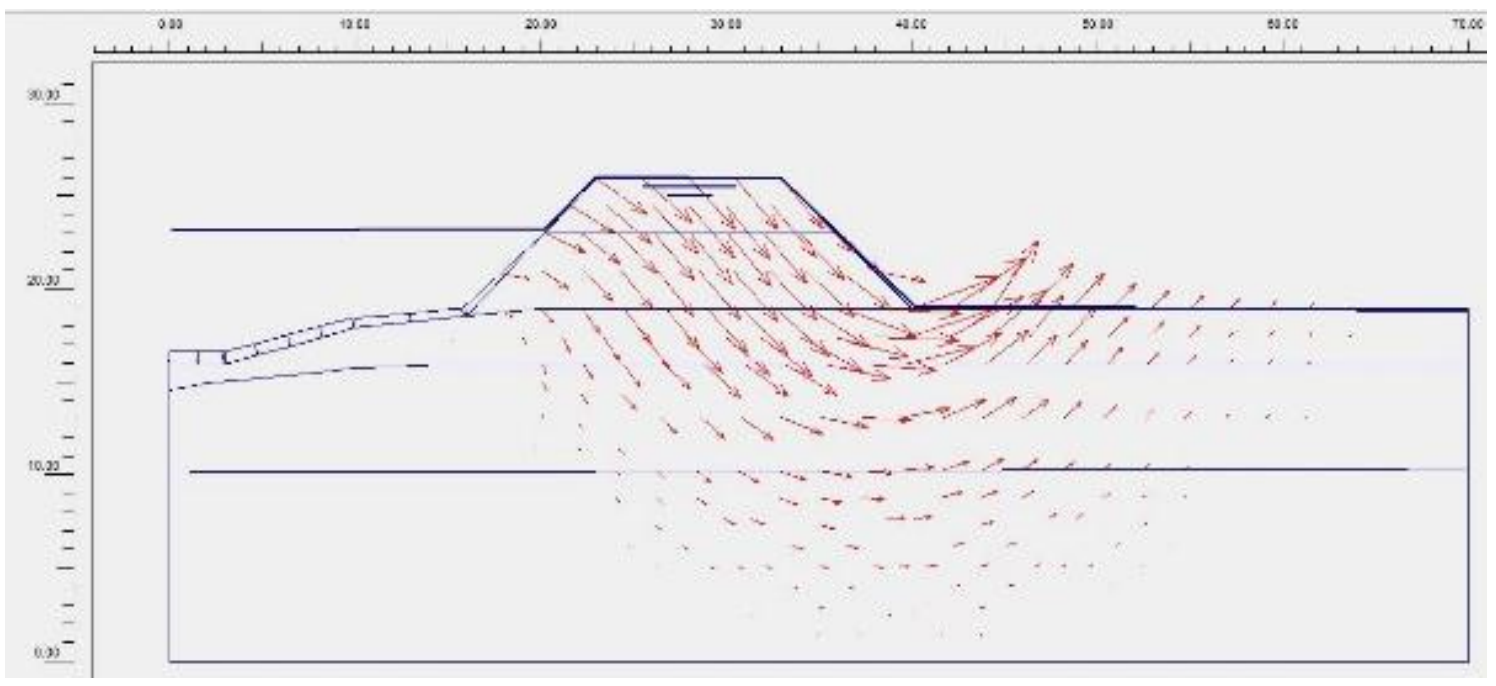

Gambar 9. Pola kelongsoran dengan kuat geser tanah timbunan tinggi (kondisi MAT.2)

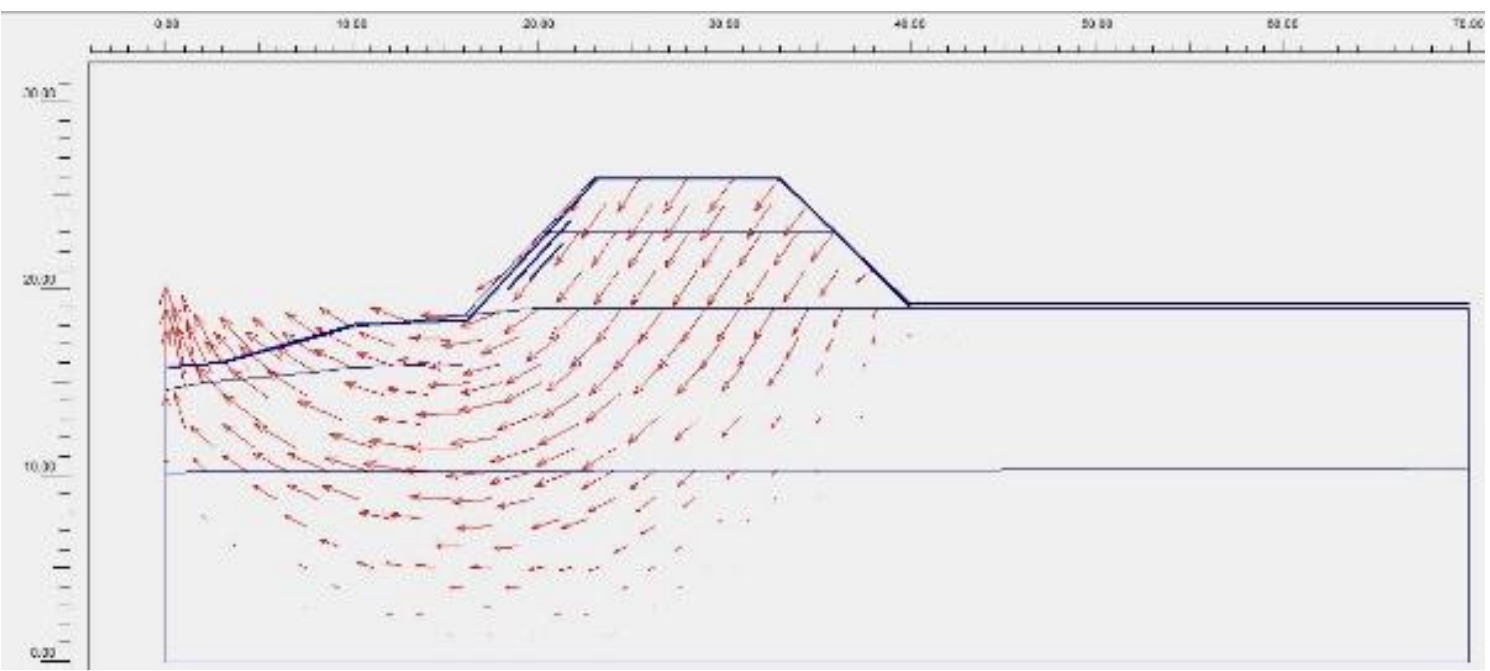

Gambar 10. Pola kelongsoran dengan kuat geser tanah timbunan tinggi (kondisi MAT.3)

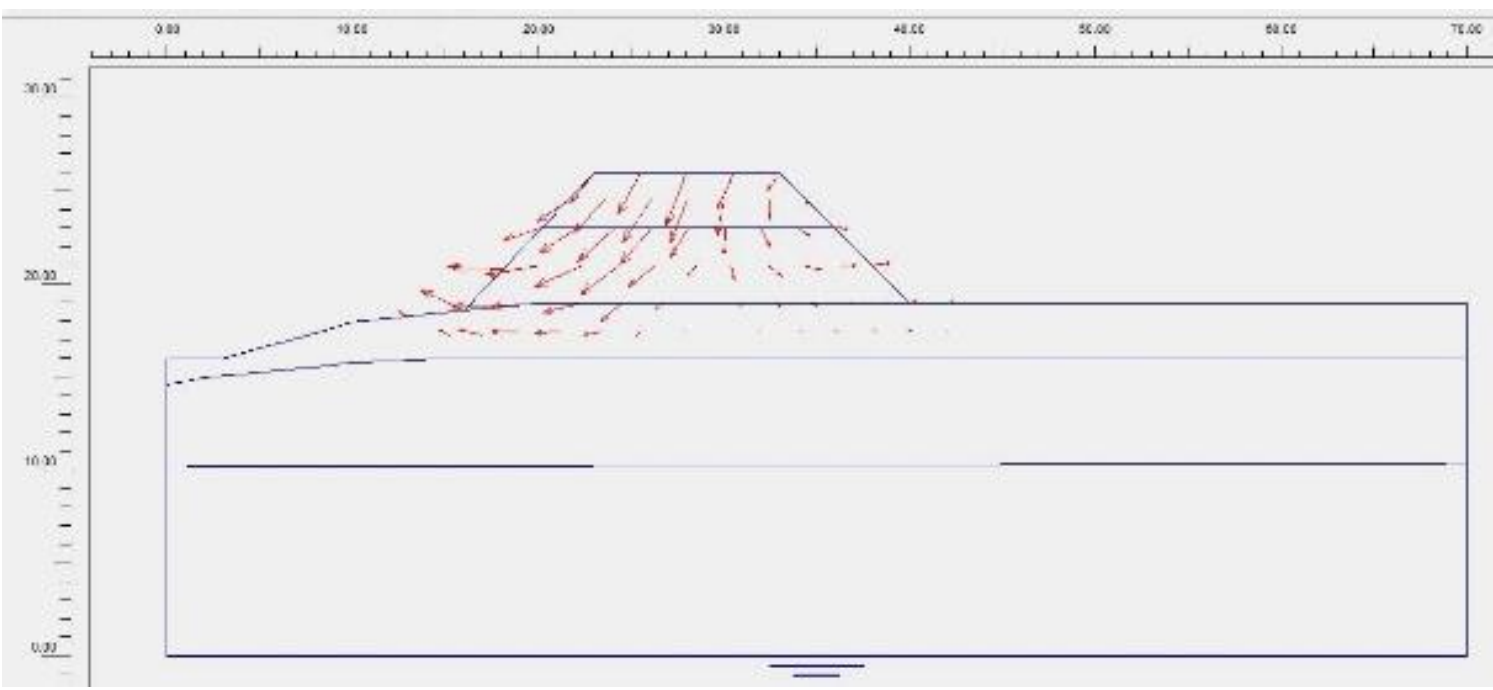

Gambar 11. Pola kelongsoran dengan kuat geser tanah timbunan rendah (tidak ada MAT) 


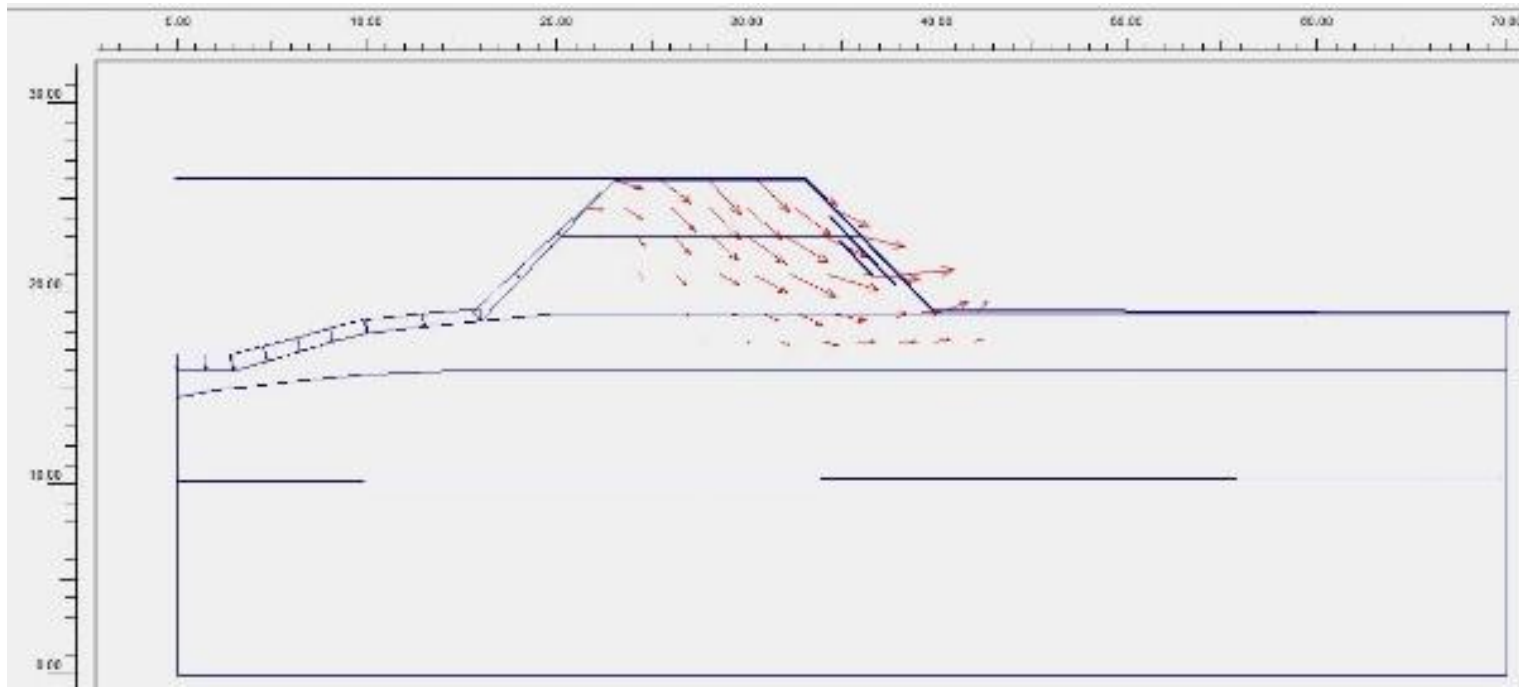

Gambar 12. Pola kelongsoran dengan kuat geser tanah timbunan rendah (kondisi MAT.1)

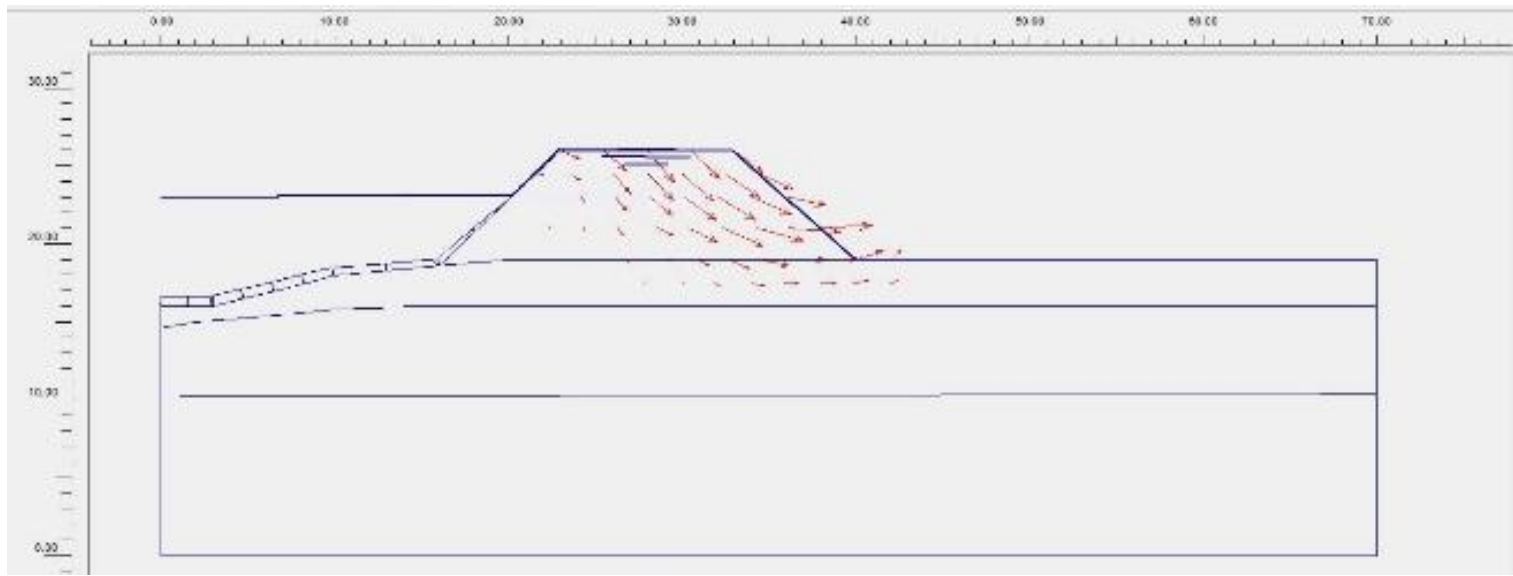

Gambar 13. Pola kelongsoran dengan kuat geser tanah timbunan rendah (kondisi MAT.2)

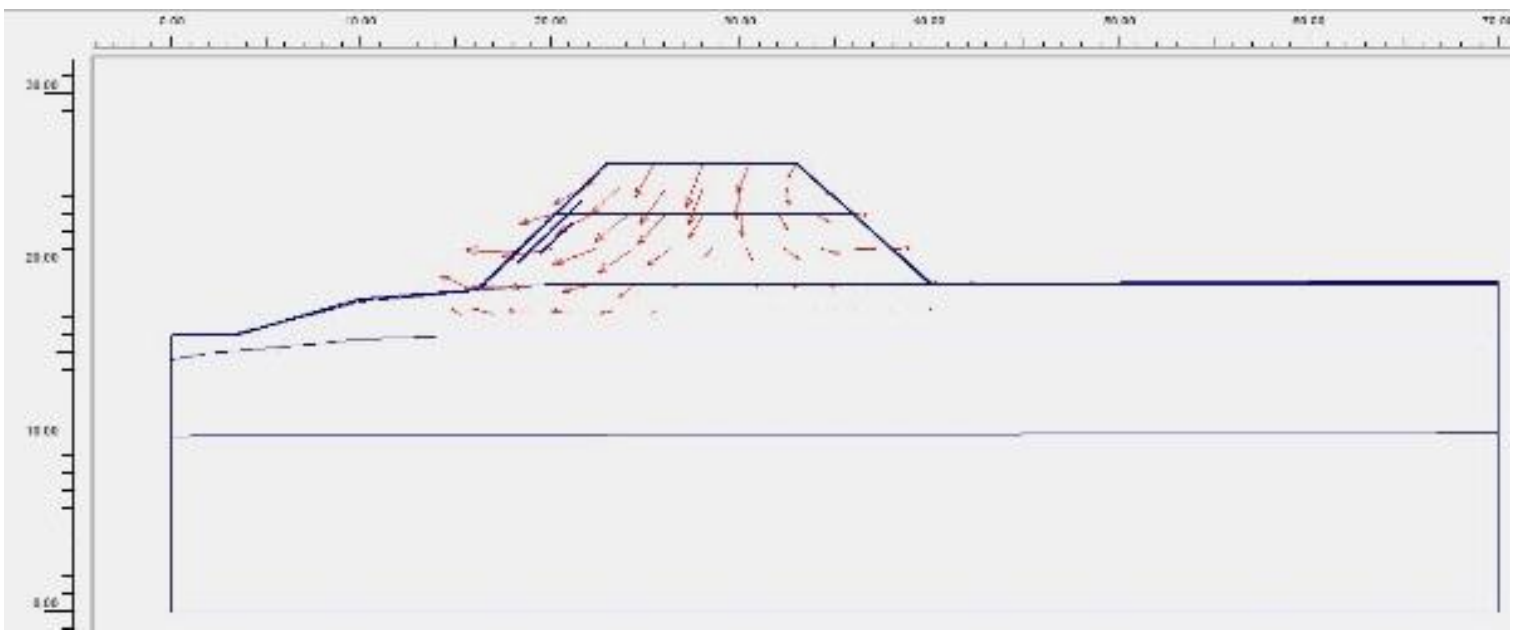

Gambar 14. Pola kelongsoran dengan kuat geser tanah timbunan rendah (kondisi MAT.3)

Peningkatan muka air tanah ke kondisi MAT 1 dan 2 menyebabkan perubahan arah kelongsoran. Pada Gambar 8 dan 9 terlihat kelongsoran lereng bergerak ke arah kanan. Perubahan arah kelongsoran ini disebabkan adanya beban air yang melawan gaya longsor sehingga angka keamanan lereng meningkat.

Hal ini berbeda pada tanah timbunan dengan kuat geser rendah. Pola kelongsoran pada tanah 
timbunan dengan kuat geser rendah hanya terjadi pada tanah timbunan seperti terlihat pada Gambar 11 sampai dengan 14 . Hal ini menunjukkan bahwa angka keamanan sebagian besar ditentukan oleh kuat geser tanah timbunan dan tidak dipengaruhi oleh kekuatan tanah dasar di bawah timbunan. Pada saat terjadi peningkatan muka air tanah, tegangan air pori meningkat sehingga tegangan efektif tanah mengalami penurunan yang pada akhirnya menurunkan angka keamanan lereng.

\section{Kesimpulan}

Berdasarkan hasil pengujian tanah di laboratorium dan analisis pemodelan dengan program Plaxis 2D untuk mengetahui pengaruh fluktuasi muka air waduk terhadap kestabilan lereng tanah timbunan di samping waduk didapatkan beberapa kesimpulan, bahwa peningkatan kadar air pada tanah kelempungan menyebabkan penurunan kuat geser tanah dimana dalam penelitian ini ditunjukkan dengan nilai CBR. Penurunan nilai CBR tanah terjadi secara signifikan ketika kadar air tanah melewati kondisi batas susut hingga mencapai kondisi batas plastis. Tanah timbunan dengan kuat geser tinggi memiliki angka keamanan yang besar dengan pola kelongsoran tanah sampai ke tanah dasar. Sebaliknya pada tanah timbunan dengan kuat geser rendah memiliki angka keamanan yang rendah dengan pola kelongsoran hanya terjadi pada tanah timbunan saja. Hal ini disebabkan karena tanah dasar memiliki kuat geser yang lebih tinggi dibandingkan tanah timbunan. Fluktuasi muka air waduk dapat menyebabkan perubahan pola kelongsoran lereng. Pada tanah timbunan dengan kuat geser tinggi $\left(c_{\mathrm{u}}>100 \mathrm{kN} / \mathrm{m}^{2}\right)$, adanya muka air waduk menyebabkan peningkatan angka keamanan tanah timbunan. Sebaliknya pada tanah timbunan dengan kuat geser rendah $\left(c_{\mathrm{u}}<100\right.$ $\mathrm{kN} / \mathrm{m}^{2}$ ), adanya muka air waduk dapat menurunkan angka keamanan.

\section{Ucapan Terima Kasih}

Peneliti mengucapkan terima kasih kepada Sally dan Elizabeth Yolanda Anggraini yang telah membantu dan mendukung proses pengumpulan data pada penelitian ini.

\section{Daftar Pustaka}

Andreea, C. (2016). Unsaturated Slope Stability and Seepage Snalysis of a Dam. Energy Procedia, $85,93-98$.

Chen, X., \& Huang, J. (2011). Stability Analysis of Bank Slope Under Conditions of Reservoir Impounding and Rapid Drawdown. Journal of
Rock Mechanics and Geotechnical Engineering, 3, 429-437.

Jenkins, P., \& Kerr, I. A. (1998). The Strength of Well Graded Cohesive Fills. Ground Engineering, 31(3), 38-41.

Keming, S., \& Bagale, M. R. (2012). Study on Dam Slope Stability Under the Condition of Rainfall. International Journal of Scientific \& Technology Research, 1(5), 39-44.

Khanmohammadi, S., \& Hosseinitoudeshki, V. (2014). The Effect of Water Level on the Stability of Slopes. Journal of Novel Applied Sciences, 3(11), 1237-1239

Liu, Q. Q., \& Li, J. C. (2015). Effects of Water Seepage on the Stability of Soil-Slopes. Procedia IUTAM, 17, 29-39.

Rahardjo, H., Nio, A. S., Leong, E. C., \& Song, N. Y. (2010). Effects of Groundwater table position and soil properties on stability of Slope During Rainfall. Journal of Geotechnical and Geoenvironmental Engineering, 136(11), 15551564.

Shivamanth, A., Athani, S. S., Desai, M. K., \& Dodagoudar, G. R. (2015). Stability Analysis of Dyke Using Limit Equilibrium and Finite Element Methods. Aquatic Procedia, 4, 884-891.

Tjandra, D., Indarto, I., \& Soemitro, R. A. A. (2013). The Effects of Water Content Variation on Adhesion Factor of Pile Foundation in Expansive Soil. Civil Engineering Dimension, 15(2), 114119.

Tjandra, D., Indarto, I., \& Soemitro, R. A. A. (2014). The Influence of Water Content Variations on Friction Capacity of Piles in Expansive Soil. International Journal of ICT-aided Architecture and Civil Engineering, 1(1), 31-40.

Tjandra, D., Indarto, I., \& Soemitro, R. A. A. (2015). Behavior of Expansive Soil under Water Content Variation and Its Impact to Adhesion Factor on Friction Capacity of Pile Foundation. International Journal of Applied Engineering Research, 10(18), 38913-38917.

Tjandra, D., Indarto, I., \& Soemitro, R. A. A. (2015). Effect of Drying-Wetting Process on Friction Capacity and Adhesion Factor of Pile Foundation in Clayey Soil. Jurnal Teknologi, 77(11), 145-150. 